\title{
MEMBACA, READING CONTEMPORARY INDONESIAN MUSLIM WOMEN WRITERS
}

\author{
Sudarmoko \\ Institute for Area Studies, Universitas Leiden \\ kokosudarmoko@yahoo.com
}

\begin{abstract}
Judul Buku: Reading Contemporary Indonesian Muslim Women Writers Penulis: Diah Ariani Arimbi | Penerbit: Amsterdam University Press, 2009 Tebal: 234 HaLAman
\end{abstract}

$\mathrm{D}$ alam beberapa dekade belakangan ini, topik keberadaan perempuan dalam sastra Indonesia telah menarik sejumlah peneliti sastra. Hal ini didukung oleh karya-karya sastra yang ditulis oleh pengarang perempuan, misalnya saja novel Saman (ditulis Ayu Utami), yang bagi banyak kalangan sering dirujuk. Pembaca karya sastra Indonesia sekarang dengan mudah mendapatkan karya-karya penulis perempuan ini di toko buku. Demikian juga dengan jenis karya populer, yang juga didominasi oleh para penulis perempuan dalam jumlah pengarang dan karyanya, dalam bentuk teenlit dan chicklit yang ditujukan untuk pembaca kalangan muda.

Buku yang ditulis oleh Diah Arimbi yang didiskusikan dalam resensi ini, Reading contemporary Indonesian muslim women writers, memaparkan pengarang perempuan dalam sastra Indonesia modern. Buku ini mengambil peran penting dalam memperdalam pengetahuan tentang keberadaan pengarang perempuan dalam sastra Indonesia modern, setelah terbitnya buku Tinneke Helwig (1994) dan juga tesis yang belum diterbitkan oleh Annabel Teh Gallop (1985) tentang S. Rukiah, makalah Manneke Budiman (2006) meneliti tentang kebangkitan dan tema perkotaan dalam karya sastra para pengarang perempuan, atau juga artikel Monika Arnez (2009) tentang Helvi Tiana Rosa dan tentu saja sejumlah tulisan lainnya. Karya-karya sastra yang ditulis oleh para pengarang perempuan, tentu saja, memberikan pandangan dan nilai estetika yang menarik untuk dibahas dalam sastra. Tidak saja persoalan tematik karya, namun juga isuisu yang selama ini tidak berhasil dimunculkan, atau setidaknya digali secara maksimal, dalam lingkup tema yang terkait. Demikian juga dengan cara membaca dan menghadapi karya-karya para pengarang perempuan itu, akan berbeda di antara pembaca laki-laki dan perempuan.

Perempuan sebagai pembaca dan perempuan sebagai penulis, merupakan alasan menarik dari buku Diah Arimbi ini. Perempuan dapat memberikan andil dalam menyampaikan pemikiran dan perasaannya melalui bacaan dan tulisan. Pandangan yang ada dalam masyarakat terhadap perempuan, khususnya terhadap kekurangan sumbangan terhadap masyarakat, idealnya ditanggapi oleh perempuan melalui karya-karya tulis. Dalam situasi seperti ini, suara perempuan dalam karya sastra, baik dalam karya kreatif maupun kritik sastra, sedikit banyak telah dimunculkan dalam karya Diah Arimbi melalui bukunya. Buku ini juga tidak melulu mendiskusikan isu tentang pengarang perempuan, tetapi juga memberikan analisis yang mendalam terhadap sejumlah karya dan pengarang yang dipilihnya. 
Buku ini dibagi dalam sebuah pengantar dan enam bagian yang disusun secara tematis. Buku yang diterbitkan oleh penerbit bergengsi secara akademik ini ditulis oleh kritikus Indonesia dan patut diberikan apresiasi.

Dengan demikian, buku ini dapat memberikan bacaan tambahan bagi para penelaah dan ahli sastra internasional, yang memiliki perhatian dalam sastra Indonesia, yang ingin mengetahui lebih mendalam tentang perkembangan sastra Indonesia oleh kritikus Indonesia. Dalam bagian pengantar, penulis menghadirkan latar belakang penelitian dan penulisan dengan menjelaskan peran perempuan dalam sastra, hubungan antara sastra dan politik, fakta dan fiksi, isi dan isu yang dihadirkan oleh pengarang perempuan yang kebanyakan didominasi oleh isu-isu privat yang dibawa ke tengah publik. Karya sastra menyediakan akses bagi isu-isu privat dan menghadirkannya ke tengah-tengah kalangan pembaca secara luas.

Diskusi mengenaiposisiperempuan dalam Islam dan masyarakat muslim dihadirkan dalam bagian pertama. Polemik tak berkesudahan ini dikembangkan oleh gerakan feminisme dan kebangkitan aktivis feminis di seluruh dunia, seperti Amina Wadud, Mernissi, Riffat Hassan, dan Amira Sonbol. Polemik ini juga terjadi di Indonesia, khususnya dalam bidang agama dan politik. Akan tetapi, fakta bahwa Megawati menjadi presiden, telah memberikan gambaran lain tentang bagaimana isu ini menyebar di Indonesia. Di negeri yang sangat heterogen ini, perdebatan tentang peran perempuan telah memengaruhi dan dipengaruhi oleh berbagai pandangan dan laku sosial, dari sudut tradisional dan modern.

Bagian dua secara khusus membahas isu-isu gender dan Islam di Indonesia. Sejumlah universitas dan lembaga penelitian, termasuk LSM, telah terlibat secara aktif dalam pemberdayaan perempuan, dengan menyokong emansipasi perempuan, penelitian, dan juga menafsirkan kembali teks-teks keagamaan tentang perempuan dan kegiatan lainnya. Perempuan dalam ruang lingkup isu ini di Indonesia telah menunjukkan gambaran lebih baik dengan meningkatnya partisipasi perempuan dalam sejumlah lapangan. Akan tetapi, tentu saja masih terdapat sejumlah keterbatasan. Pertumbuhan dan dinamika gerakan feminis juga terlihat dalam sejumlah karya sastra, yang dapat dirujuk dalam analisis instrinsik dalam buku ini.

Arimbi dalam bagian tiga menghadirkan gambaran umum mengenai pengarang perempuan di Indonesia. Mereka telah hadir dalam sastra Indonesia sejak awal namun sekadar menjadi pelengkap. Arimbi memiliki beberapa contoh dari analisisnya sejak tahun

1970an hingga terkini. Hal ini ditandai dengan tersebarnya sastra populer di Indonesia, dan kebanyakan ditulis oleh perempuan. Meningkatnya jumlah pengarang perempuan yang menulis sastra populer juga membawa isuisu khas dalam karya mereka.

Analisis dilakukan terhadap empat pengarang perempuan, yaitu Titis Basino, Ratna Indraswari Ibrahim, Abidah El Khaliqiy, dan Helvi Tiana Rosa. Di bagian empat, Arimbi memberikan biografi yang rinci dari setiap pengarang. Di bagian ini, Arimbi tidak hanya menyajikan karya-karya dan kehidupan pengarang, namun juga pandangan mereka terhadap masyarakat, isu-isu perempuan, serta estetika sastra. Dua bagian selanjutnya mengupas karya masing-masing pengarang, dan yang penting dari buku ini, masalah-masalah dan pandangan terkait dengan perempuan. Penjelasan pada bagian awal buku ini tentang posisi dan peran perempuan dalam masyarakat membawa kita untuk memahami bagian akhir buku ini. Karya sastra sebagai representasi dari keadaan sosial menceritakan lebih dalam tentang pengarang perempuan dan khususnya suara-suara perempuan dan berbagai topiknya.

Bagian lima berisi analisis karya-karya Titis Basino dan Ratna Indraswari. Kemudian dua pengarang lainnya dihadirkan dalam bagian enam. Arimbi dengan hati-hati membaca dan menganalisis karya mereka dan membuat sejumlah catatan sesuai dengan tema karya tersebut. Masalah-masalah yang hadir dalam 
karya yang dibahas itu menyediakan bukti tentang gambaran perempuan dan realitasnya dalam karya sastra dan kehidupan sosial. Arimbi mencoba untuk memberikan gambaran dan alasan yang seimbang dalam memilih contoh analisis dan menghadirkan pengaruh masyarakat muslim terhadap pengarang, dan keterlibatan dalam emansipasi perempuan, usia, dan latar belakang sosial.

Dua bagian berikutnya merupakan dasar dari analisis karya sastra sebagai topik utama dari buku ini. Dengan sejumlah persoalan yang dihadirkan dalam buku ini, Arimbi memberikan nilai penting dalam lapangan pengetahuan, terutama bagi kajian sastra Indonesia, bagi para ahli sastra dan ilmu sosial, mahasiswa, aktivis feminisme, dan mereka yang ingin mengetahui arti penting sastra dalam kehidupan sosial budaya.

\section{Referensi}

Budiman, Manneke, 2006. "Viewing the Nation from the City in Contemporary Indonesian Women's Urban Writing", dalam Arts, Popular Cultures and Social Change in the New Indonesia, Michael Leaf, ed.UBC, Canada, pp. 13-32.

Gallop, Annabel Teh. 1985. The work of S. Rukiah. (Unpublished Masters Dissertation, SOAS).

Arnez, Monika. 2009. "Dakwah by Pen Reading Helvy Tiana Rosa's Bukavu” Indonesia and the Malay World, 1469- 8382, Vol. 37(107), 2009, Pp. 45 - 64.

Hellwig, Tineke, 1994. In the Shadow of Change Images of Women in Indonesian Literature. Berkeley, University of California: Center for Southeast Asia Studies. 